\title{
THE INFLUENCE OF THYMIC EXTRACT ON HEMATOLOGICAL PARAMETER VALUES IN IRRADIATED WISTAR RATS
}

JOVANOVIĆ $\mathrm{M}^{\star}$, LAZAREVIĆ $\mathrm{M}^{*}$, POPOVIĆ $\mathrm{N}^{\star}$ and ĐURĐEVIĆ $\Xi^{* *}$

*Faculty of veterinary medicine, Belgrade; **Military medical academy, Belgrade

\author{
(Received 17. February 2006)
}

In this study, results obtained by following up the changes in hematological parametar values in Wistar rats irradiated with 4 Gy and treated with calves thymic extract Thymex-L are presented. Following irradiation, white blood picture parametars were dramatically decrased and gradually increased from day 14. This elevation was higher in the Thymex- $L$ treated group and the differences were statistically significant for total leukocyte, lymphocyte and neutrophyl granulocyte count starting from day 14. A significant increase of the monocyte count was observed only at day 28. Parametars of the red blood picture (erythrocyte count, hemoglobin concentration and packed red blood cell volume) were increased starting from day 21.

We were able to conclude that treatment of irradiated Wistar rats with thymic extract results in a significant improvement of hematological parametar values. extract

Key words: rats, irradiation immunomodulation, calfs thymic

\section{INTRODUCTION}

Immunomodulation is a phenomenon based on the influence of different endogenous and exogenous substances on immune cells and molecule functions. Substances which show the ability to influence the immune response are called immunomodulators and can be distinguished as stimulators or suppressors. Some immunomodulators are immunobiological products (vaccines, microbial products) while others belong to antibiotics and hemotherapeutics. The majority of immunomodulators enhances or suppresses immune reactions showing no antigen specificity. Some of them may exert both effects depending on the dose and route of application (Tizard 2004, Nestorova, 1999).

The main target cells for immunomodulators are the T and B lymphocytes, monocytes, macrophages and granulocytes. The precise mode of immunomodulatory activity is not elucidated in detail, but most of them influence levels of CAMP and cGMP in the cell cytoplasm changing their ratio. Elevation of 
the cAMP level results in immunosuppressiom while cGMP has stimulatory effects (Nestorova, 1999).

The use of immunosuppressive substances and methods is important for the sanation of auto reactive conditions, allergic reactions and prevention of transplant rejections. These methods and substances can be nonspecific (antigen independent) and specific (antigen dependent) (Lake et al., 2001). Techniques used for immunosuppression are based on $\mathrm{X}$ ray irradiation and on the effects of some drugs on cell replication.

Immunosuppression by $X$ ray irradiation is a consequence of its activity towards nucleic acids, which results in potentially lethal mutations of progenitor cells. Moreover, in irradiated cells the formation of peroxides is stimulated leading to toxic effects. Especially important are reactive oxygen species that cause irreversible changes in the membrane polyunsaturated fatty acids. X-ray irradiation also causes changes in the nuclei and genetic material (Bethseda, 2001). Generally, cells with intensive metabolism and cells in the process of division, like the cells of the immune system, are more susceptible (Ricoul and Dutrillaux, 1991).

A dose that exerts immunosuppressive effects depends of the species and breed especially in laboratory animals. The mean lethal dose $\mathrm{LD}_{50 / 30}$ in mice, rats and hamsters is 6-8 Gy, while in bigger animals (pig, dog, sheep) $L^{5_{0 / 30}}$ is 2.23.5 Gy (Bond, 1964). There are also differences in radio-resistance regarding sex, age, physiological conditions and intensity of metabolism. Some mice strains are more resistant e.g. $\mathrm{C} 57 \mathrm{BL} / 6$ vs. BALB/c with $\mathrm{LD}_{50 / 30}$ of 8.308 and 5.985 Gy respectively (Radojčić, 1990).

Mature cells in the peripheral blood have limited, relatively short life spans and they are being gradually replaced. Blood cells like monocites, erythrocytes, granulocytes, and thrombocytes are radio resistant when exposed to irradiation doses that affect bone marrow cells (Gasper, 2000). They can circulate in the blood with preserved functions, even following irradiation. On the contrary, stem cells are very sensitive and therefore the production of young cells is disturbed resulting in decreased blood cell count in accordance to their life span. Granulocyte count reaches the lowest value 5-10 days following irradiation depending of the dose applied. The period of recovery also depends on the dose, and if relatively high doses of irradiation are applied, neutropenia can be prolonged resulting in lethal infections (Muira, 2000). Thrombocyte count reaches the lowest value approximately 10 days following irradiation depending of the dose applied (Ziablitski et al., 1997). The recovery process is similar as in granulocytes and usually lasts about three weeks. Erythrocyte count, packed cell volume and hemoglobin concentration also show a decreasing tendency parallel to death of mature cells. In rats which received a 4 or 6 Gy dose, this decrease is relatively slow but in animals irradiated with 8 Gy these values reache the lowest level 14 days following irradiation (Simović, 1983). The recovery period is slower than in granulocytes and thrombocytes. Unlike the above mentioned cells, circulating lymphocytes are extremely sensitive to irradiation and they disappear from the circulation rapidly. 
Acta Veterinaria (Beograd), Vol. 56. No. 2-3, 137-148, 2006.

Numerous peptides isolated from thymic extracts express immunostimulatory effects. In this category are thymosine, thymic humoral factor, thymopoetin, thymostymulin and thymuline. These hormones stimulate maturation and differentiation of T-lymphocytes, up regulate Th and Tc lymphocyte activity (thymic humoral factor), and increase synthesis of IL-2 and IFN- $\gamma$ (thymostimuline) and increase defense against viruses (thymosine) (Munno et al. 1995, Benedickt 2000, Wilson 2000). Some of them have positive therapeutical effects, but their use in medical practice is still under observation. They are frequently used in therapy of respiratory diseases, various infections, immunodeficiency, skin diseases, neoplasms and following surgical interventions. Thymic extracts can be efficient in different animal species like dogs, rabbits and swine (Barbaroza et al., 2000).

\section{MATERIAL AND METHODS}

This study was conducted on 80 highly inbred, male Wistar rats, aged 3 months and $200-300 \mathrm{~g}$ body weight. Animals were kept in propylene cages in groups of 5 under constant microclimate conditions on $18-22{ }^{\circ} \mathrm{C}$ and 22 air changes per hour. They were fed commercial feed and had free access to water. Rats were divided in two equal groups ( $T$ - treated and UT - untreated). At the beginning of the experiment blood samples were taken from 20 animals $(10 \mathrm{~T}+$ 10 UT) by medial eye sinus puncture. On the following day, all animals were subjected to whole body irradiation with $4 \mathrm{MeV}$ X-rays at a dose of 4 Gy by linear accelerator SLi ELEKTA (USA).

Rats from the treated group $(\mathrm{T})$ were injected subcutaneously with $15 \mathrm{mg}$ of Thymex- $L$ aqueous solution every other day following irradiation till the $26^{\text {th }}$ day. One original package of Thymex-L (Thymorgan - GmbH Pharmazie \& Co. KG. Germany) contains $150 \mathrm{mg}$ of the whole thymic extract THX (Dr Pesic) obtained from the thymic gland of young calves. This extract is standardized in respect to protein concentration $(0.6 \mathrm{mg} / \mathrm{mg}$ of proteins, $\mathrm{pH} 7.1)$. Apart from immunogenic peptides, Thymex-L contains active adenosin-desaminases, purine-nucleoside phosphatases, superoxy dismutase, glutathione reductase, glutathione-Stransferase, glutathione peroxydase and peptidase. Rats from the untreated group (UT) were injected subcutaneously with $0.2 \mathrm{ml}$ of sterile physiological saline every other day following irradiation till the $26^{\text {th }}$ day.

Following irradiation, blood samples were taken on days 4, 7, 11, 14, 18, 21, 25 and 28. in tubes containing 25000 IU of Na-heparinate. All hematological analyses (total leukocyte, lymphocyte, neutrophyl granulocyte, monocite, erythrocyte, thrombocyte count, hemoglobin concentration and packed cell volume) were performed on the automatic analyzer "Diatron-Arcus" (Austria).

Statistical analyses was performed by calculating the mean values and standard deviations. Statistical significance between obtained mean values was estimated by Student's t-test. 


\section{RESULTS}

Results obtained in this study are presented on Figures 1-8, while the statistical significance of differences between mean values for the observed parameters during the 28 days of trial are given in Table 1 .

The total leukocyte count was significantly lowered on days 4 and 7 (Figure 1), and was followed by the gradual increase in both experimental groups (T and UT) till the end of the trial. Statistical differences between groups were significant from day 11 till day 28 (Table 1) and mean values were higher in the Thymex-L treated group $(\mathrm{T})$.

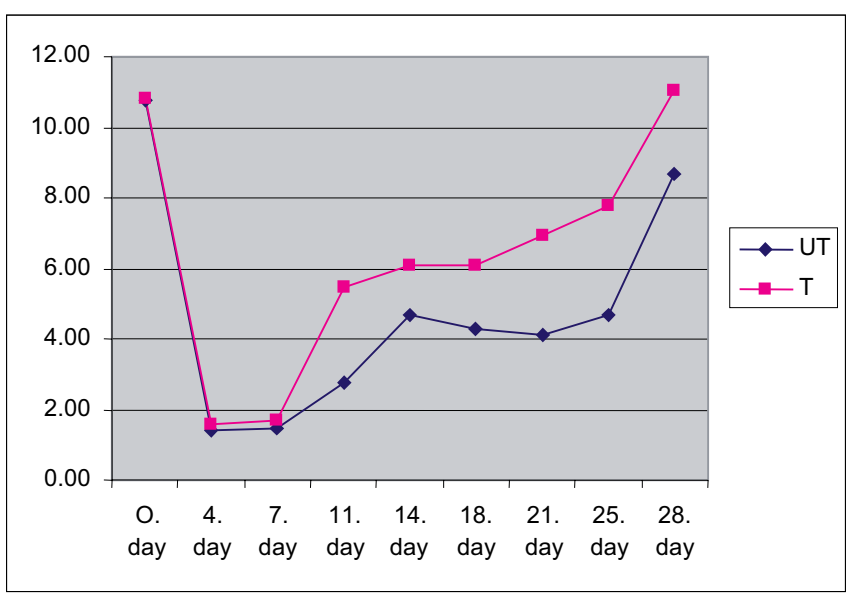

Figure 1. Total leukocyte count $\left(\mathrm{n} \times 10^{9} / \mathrm{L}\right)$ in Thymex-L treated $(\mathrm{T})$ and untreated (UT) irradiated Wistar rats during 28 . days of trial

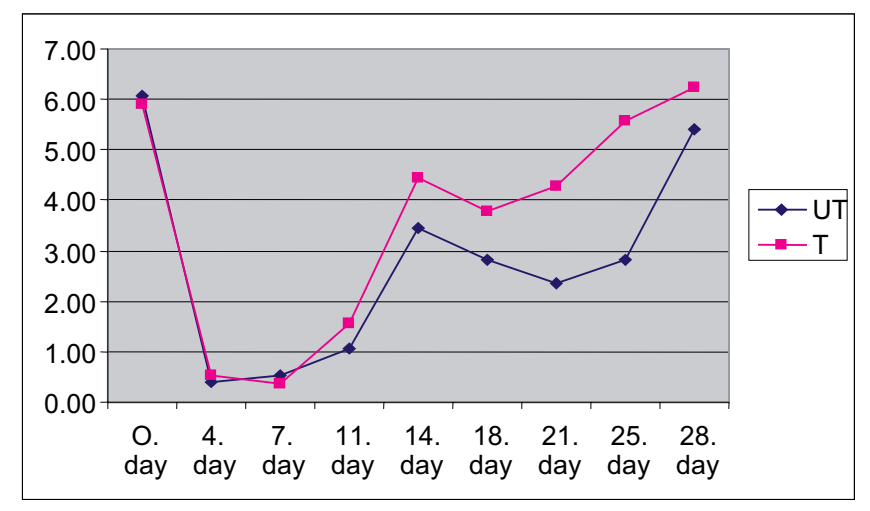

Figure 2. Lymphocyte count $\left(n \times 10^{9} / \mathrm{L}\right)$ in Thymex-L treated (T) and untreated (UT) irradiated Wistar rats during 28 . days of trial 
Acta Veterinaria (Beograd), Vol. 56. No. 2-3, 137-148, 2006.

A marked decrease in lymphocyte count was registered on day 4 of the experiment and lasted till day 11 in both experimental groups (Figure 2). Latter, the number of lymphocytes showed a tendency to increase and reached the initial values on day 28 . Statistical differences were significant between groups from day 14 till day 28 and mean values were higher in group T (Table 1).

Like for the two previous cell types, a marked decrease in monocyte count was registered on day 4 of the experiment and lasted till day 11 in both experimental groups (Figure 3). However, the number of monocytes exhibited a very slow tendency of increase (more prominent in group T) and did not reach initial values till the end of the trial. Statistical differences between the mean values were significant only at day 28 (Table 1 ).

Number of neutrophile granulocytes was markedly decreased on days 4 and 7 of experiment (Figure 4). From that point onwards, we were able to

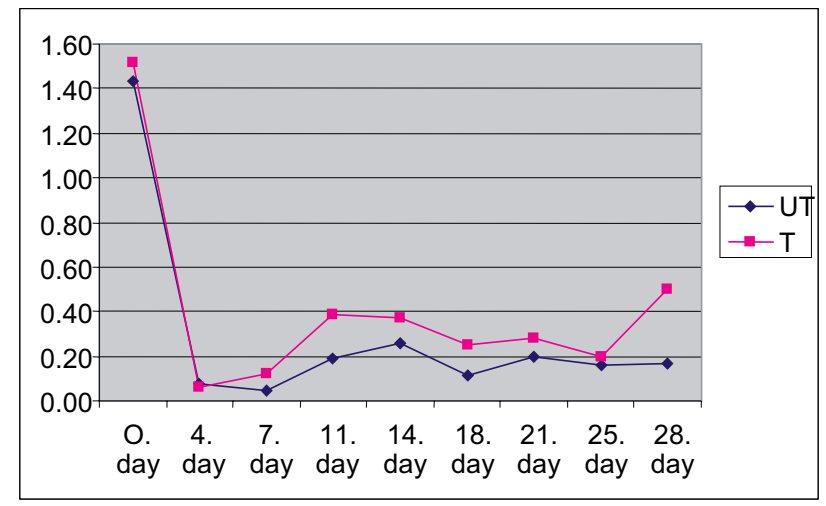

Figure 3. Monocyte count ( $\left.\mathrm{n} \times 10^{9} / \mathrm{L}\right)$ in Thymex-L treated $(\mathrm{T})$ and untreated (UT) irradiated Wistar rats during 28 days of trial

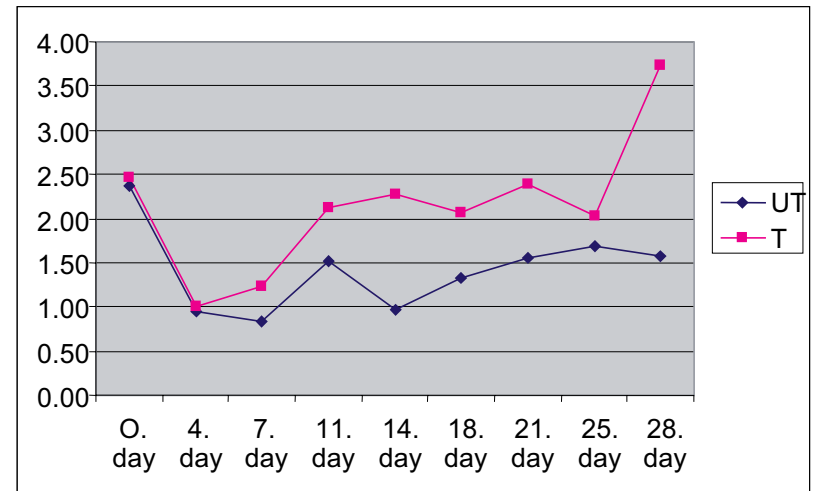

Figure 4. Neutrophile granulocyte count $\left(\mathrm{n} \times 10^{9} / \mathrm{L}\right)$ in Thymex-L treated $(\mathrm{T})$ and untreated

(UT) irradiated Wistar rats during 28 days of trial 
demonstrate a gradual increase, more prominent in the Thymex-L treated group. Increasing tendency was slow and values, higher than initial ones, were recorded in the Thymex-L treated group. Statistical differences between groups were significant starting from day 11 (Table 1).

Changes in red blood picture parameters (erythrocyte count, hemoglobin concentration and packed red blood cells volume) following irradiation and Thymex-L treatment are presented on Graphs 5, 6 and 7.

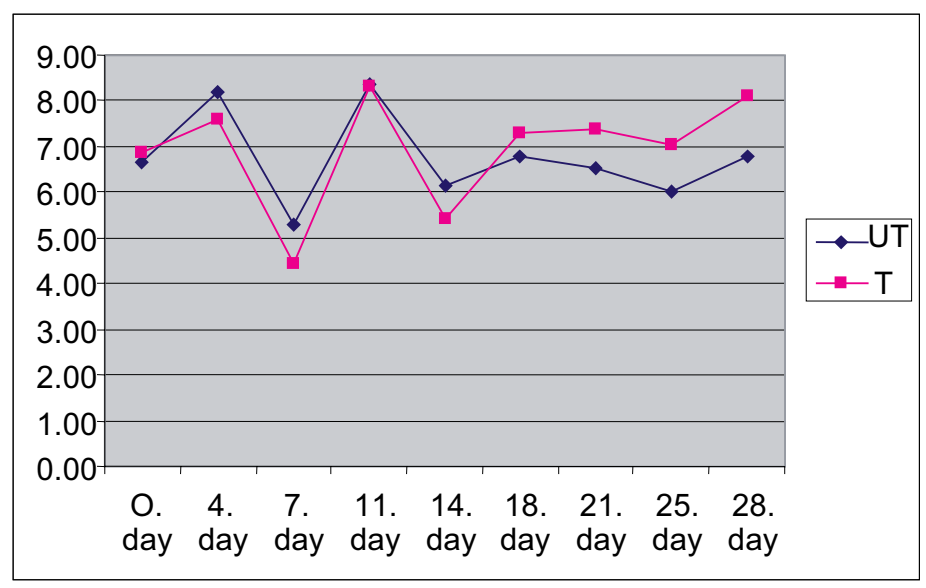

Figure 5. Erythrocyte count $\left(\mathrm{n} \times 10^{12} / \mathrm{L}\right)$ in Thymex-L treated $(\mathrm{T})$ and untreated (UT) irradiated Wistar rats during 28 days of trial

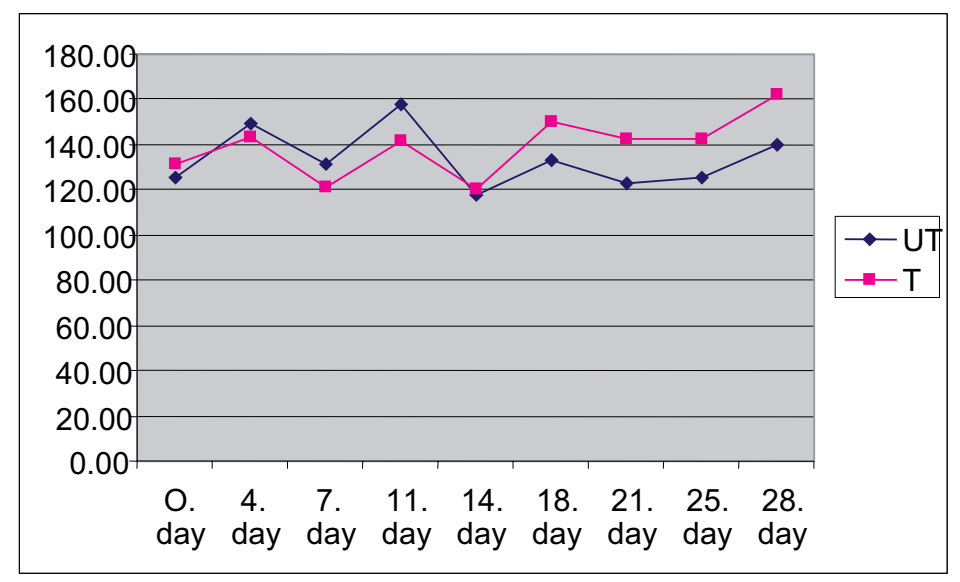

Figure 6. Hemoglobin concentration in Thymex-L treated (T) and untreated (UT) irradiated Wistar rats during 28 days of trial 
Acta Veterinaria (Beograd), Vol. 56. No. 2-3, 137-148, 2006.

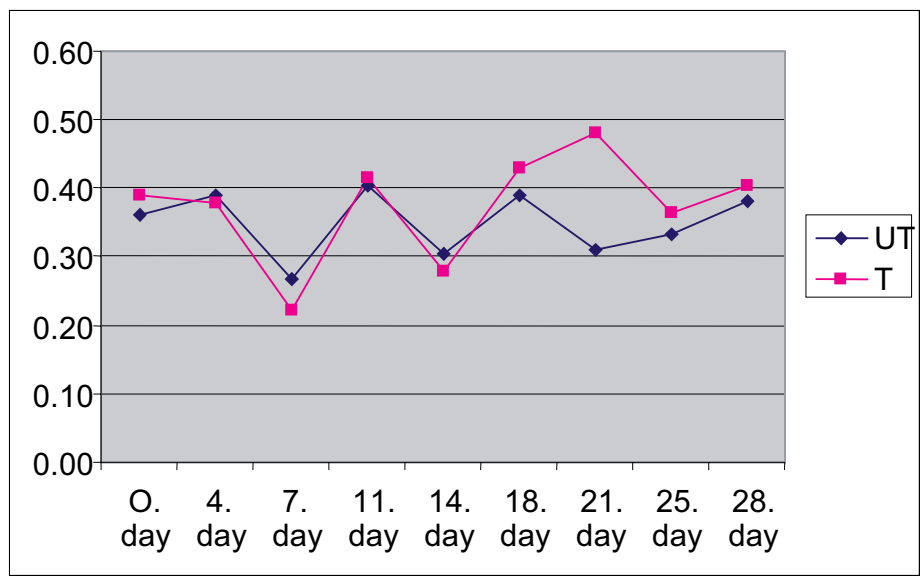

Figure 7. Packed red blood cell volume in Thymex-L treated (T) and untreated (UT) irradiated Wistar rats during 28 days of trial

Unlike in other observed hematological parameters, these values were not significantly changed on day 4 of the trial and till day 14 showed unpredictable variations, not connected with the treatments. After that, till the end of the trial, a significant increase was documented in the Thymex- $L$ treated group for all three parameters (Table 1).

The number of thrombocytes gradually decreased till day 11 and a significant increase was registered on day 14 in both groups (Figure 8). After that,

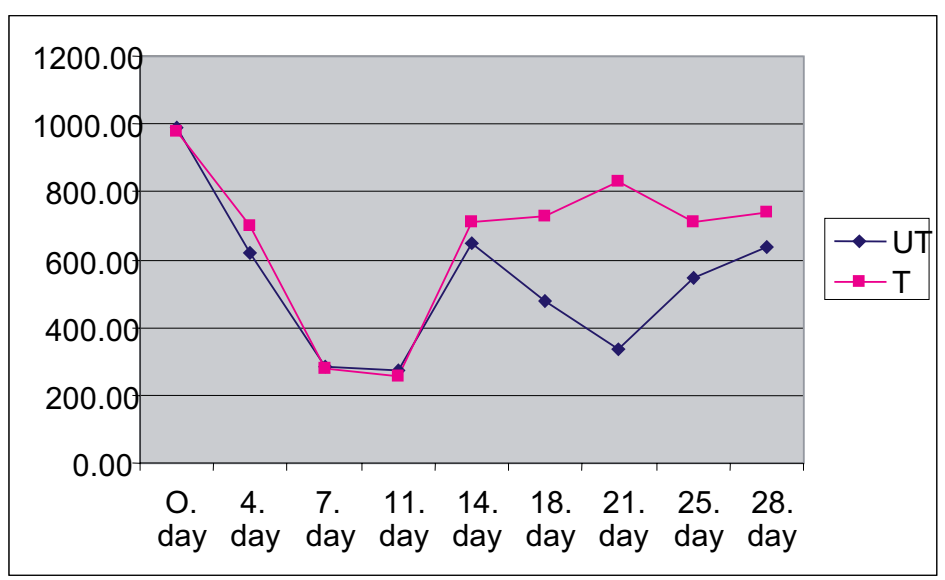

Figure 8. Thrombocyte count $\left(\mathrm{n} \times 10^{9} / \mathrm{L}\right)$ in Thymex-L treated (T) and untreated (UT) irradiated Wistar rats during 28 days of trial 
the number of thrombocytes fall again in the untreated group which was not the case in group T. The statistical differences in mean values between groups were significant on days 21 and 25 (Table 1).

Table 1. Statistical differences between hematological parameters in Thymex- $\mathrm{L}$ treated (T) and untreated (UT) irradiated Wistar rats during 28 days of trial

\begin{tabular}{|c|c|c|c|c|c|c|c|c|}
\hline & $\begin{array}{c}\text { Le } \\
\text { UT vS T }\end{array}$ & $\begin{array}{c}\text { Lym vs T } \\
\text { UT vsT }\end{array}$ & $\begin{array}{c}\text { Ne } \\
\text { UT vS T }\end{array}$ & $\begin{array}{c}\text { Er } \\
\text { UT vs T }\end{array}$ & $\begin{array}{c}\text { Hb } \\
\text { UT vs T }\end{array}$ & $\begin{array}{c}\text { PCV } \\
\text { UT vS T }\end{array}$ & $\begin{array}{c}\text { Tr } \\
\text { UT vS T }\end{array}$ \\
\hline \hline $\begin{array}{c}4 . \\
\text { day }\end{array}$ & NS & NS & NS & NS & NS & NS & NS & NS \\
\hline $\begin{array}{c}7 . \\
\text { day }\end{array}$ & NS & NS & NS & NS & NS & NS & NS & NS \\
\hline $\begin{array}{c}11 . \\
\text { day }\end{array}$ & $p<0.001$ & NS & NS & $p<0.001$ & NS & NS & NS & NS \\
\hline $\begin{array}{c}14 . \\
\text { day }\end{array}$ & $p<0.05$ & $p<0.05$ & NS & $p<0.05$ & $p<0.05$ & NS & $p<0.05$ & NS \\
\hline $\begin{array}{c}18 . \\
\text { day }\end{array}$ & $p<0.01$ & $p<0.05$ & NS & $p<0.05$ & NS & $p<0.01$ & NS & NS \\
\hline $\begin{array}{c}21 . \\
\text { day }\end{array}$ & $p<0.05$ & $p<0.05$ & NS & $p<0.05$ & $p<0.001$ & $p<0.001$ & $p<0.001$ & $p<0,001$ \\
\hline $\begin{array}{c}25 . \\
\text { day }\end{array}$ & $p<0.001$ & $p<0.001$ & NS & $p<0.05$ & $p<0.01$ & $p<0.05$ & NS & $p<0,01$ \\
\hline $\begin{array}{c}28 . \\
\text { day }\end{array}$ & $p<0.05$ & $p<0.05$ & $p<0.01$ & $p<0.001$ & $p<0.001$ & $p<0.001$ & $p<0.05$ & NS \\
\hline
\end{tabular}

NS- non significant

\section{DISCUSSION}

Four days after whole body X-ray irradiation of Wistar rats (4 Gy) we were able to demonstrate a significant decrease in the total leukocyte, lymphocyte, monocyte and neutrophile granulocyte counts. This was a consequence of the $X-$ ray action on the bone marrow progenitor cells and also a consequence of the short life span of blood cells (Boggs, 1967, Bintom et al. 1971, Grindem 1989, Gasper, 2000). This is in agreement with our previous results (Jovanović et al., $2005,2005 a$ ) and also with results of other authors who conducted similar trials on rats (Simović, 1983, Miura et al., 2000). In experiments on goats and pigs, Milošević et al. (2004) demonstrated the same outcome of X-ray irradiation on leukocyte, lymphocyte and neutrophile granulocyte counts which decreased to $20 \%$ of the initial values during the first few days following irradiation. Similar to our findings, the number of these cells in the circulation increased gradually and reached initial values one month after irradiation. 
Acta Veterinaria (Beograd), Vol. 56. No. 2-3, 137-148, 2006.

Values obtained for the parameters of the red blood picture also showed a tendency to decrease, but gradually, according to the longer life span of the red blood cells. As erythrocytes can live several months, in some species effects of irradiation were observed later on (Christian, 2000). In our study we documented a significant decrease of their values with some minor variations two weeks following irradiation. These results are in agreement with our previous findings (Jovanović et al., 2005, 2005a) as well with the results of other authors (Simović, 1983; Milošević, 2004).

Thrombocytes in rats have a life span of 5 days and represent the most important cellular element of hemostasis (Hawkey et al., 1990). Their number decreases following irradiation and reaches the lowest level in approximately 10 days (Glass et al., 1983; Christian, 2000). In our study the lowest thrombocyte count was recorded from the $7^{\text {th }}$ to the $14^{\text {th }}$ day of trial. Their recovery is similar to granulocytes and stars from the $3^{\text {rd }}$ week following irradiation. X-ray irradiation of rats with a total dose of 4 Gy caused a marked thrombocytopenia on day 14 (Simović, 1983; Milošević, 2004).

Immunostimulatory effects of the thymic extracts is based on the activity of numerous peptides that can be isolated from the gland. They enhance maturation and differentiation of T-cells, stimulate activity of Th and Tc cells, up regulate IL-2 and IFN- $\gamma$ production and increase the defense against viral agents.

We were able to demonstrate the statistically significant $(p<0.01)$ elevation in the total leukocyte, lymphocyte and neutrophile granulocytes number in the group of Thymex-L treated rats appeared from day 14 and lasted till the end of the investigation (day 28). These results are in agreement with data of Czaplicki et al. (1981) who investigated the influence of calf's thymic extract on irradiated mice. These authors proved that irradiated and treated animals had higher lymphocyte count, attenuation of the radiation syndrome and live longer than untreated ones. In another study Czaplicki et al. (1992) reported lymphocyte count elevation and hyper-gammaglobulinaemia in irradiated and Thymex- $L$ treated neonatal thymectomised or lethally irradiated mice. Immunostimulatory effects of thymic extracts have also been documented in other animal species (dogs and poultry) resulting in better immune response and leukocyte count (Montoya et al., 1990; Fatteh et al., 1999; Barboza et al., 2000).

The influence of thymic extract on the activity and proliferative response of mononuclear cells has also been investigated in vitro. Incubation of lymphocytes with Thymex-L resulted in higher T cells activity, and better proliferative response in patients with lung cancer (Vučković-Dekić et al., 1994). Thymex-L increased in vitro tumorostatic activity of monocytes and production of TNF $\alpha$ in melanoma patients (Garbin et al., 1995).

Apart from the positive influence of calf's thymic extract on the white blood cells count we were able to demonstrate a significant increase of the red blood picture parameters starting from day 21 following irradiation. Blonska et al. (1992) demonstrated a decrease of red blood cells count followed by increased $\mathrm{MCH}$ (mean corpuscular hemoglobin) and $\mathrm{MCHC}$ (mean corpuscular hemoglobin concentration) in Thymex-L treated mice that were not exposed to irradiaton. In our study Thymex-L also increased the number of thrombocytes in Wistar rats but 
only starting from day 21 of the experiment. It has been demonstrated that in rabbits with coagulation disorders Thymex-L regulates thrombocyte count and partial tromboplastine time, thus normalizing blood coagulation processes (Ossowicka-Stepinska et al., 1999).

Our results indicate that the negative effects of $X$-ray irradiation on hematological parameters values in Wistar rats can be restored by treatment with calf's thymic extract.

Address for correspondence:

Mr Milan Jovanović

Faculty of Veterinary Medicine

Bul. Oslobođenja 18

11000 Beograd, Serbia and Montenegro

e-mail: milanjov@vet.bg.ac.yu

\section{REFERENCES}

1. Barboza G, Rivera S, Parra O, Fernandez G, Ramirez R, Otero C, 2000, Evaluation of immunological response in canines infected with demodectic mange after tretment with Amitraz or Thymostimulin Tp-1, Rev Cient-Fac de Cienc Vet, 10, 2, 145-52.

2. Benedikt $H, 2000$, The use of Thymus Supplementation: A Novel Approch to Immune Regulation, Orig Int, $20-5$.

3. Bethesda MD, 2001, Molecular and Celular Biology of moderate Dose (1-10 Sv) Radiation and Potential Mechanisms of Radiation Protection, Proceedings Moderate Dose Radiation Workshop Draft Report, 1-22.

4. Bintom DF, Ullyot JL, Farquhar MG, 1971, The development of neutrophilic polymorphonuclear leukocytes in human bone merrow, $J$ Exp Med, 134, 907-15.

5. Blonska B, Czaplicki J, Pešić CM, Klementys A, Cwiertka P, 1992, Erythrocyte parameters in mice treated with embryonal and early fetal thymic calf extracts (ETCE) and mature calf thymic extracts (Thymex-L and TFX-Polfa), Thymuspeptide Timusenzime Thymushormone in Forschung und Therapie, Thynus Medizinischer Fachbucherlag, Bad Harzburg, 139-46.

6. Boggs DR, 1967, The kinetics of neutrophils leukocytes in health and disease, Semin Hematol, 4, 359-86.

7. Bond V, 1964, Comparsion of the mortality response of different mamalian species to X-rays and fast neutrons, Proc. of Symposium on biological effects of neutron and proton irradiation, II. IAEA, Viena, 370.

8. Christian AJ, 2000, Red Blood cell Surivival and Destruction, In: Feldman FB, Zinkle GJ, Nemi CJ, editors, Schalm's Veterinary Hematology, $5^{\text {th }}$ ed Lippincott Williams \& Wilkins, Philadelphia, 117-24.

9. Czaplicki J, Blonska B, Stec L, 1981, The effect of embryonal thymic calf extracts on neonataly thymectomized mice and on mice lethally irradiated with gamma rays, Thymus, 3, 143-51.

10. Czaplicki J, Blonska B, Pešić CM, Klementys K, Grzybek H, Brandys B, Becker C, 1992, Tyhmys morphology in aging mice treated with embryonal and early fetal thymic calf extracts (ETCE) and mature calf thymic extracts (Thymex-L and TFX). Thymuspeptide Timusenzime Thymushormone in Forschung und Therapie. Thymus Medizinischer Fachbucherlag, Bad Harzburg, 111-28.

11. Fattah MAF, El-Hamamy MM, El-Shahedy M, Gehad M, 1999, Effect of Thymus extract on Immunologic reactivity of Chiken Vaccinated with Infectious Bursal Disease Virus, $J$ Vet Med Sci, 61,7, 811-7.

12. Gasper WP, 2000, The hemopoietic System. In Feldman FB, Zinkle G.J, Nemi CJ, Schalm's Veterinary Hematology. $5^{\text {th }}$ ed Lippincott Williams \& Wilkins, Philadelphia, 63-73. 
13. Garbin F, Eckert K, Buttner P, Garbe C, Czarnecki J, Rainer Maurer H, 1995, The influence of the thymic preparation Thymex-L on deficient antitumor activity of monocytes from melanoma patients in vitro, Onc Rep, 2, 10-4.

14. Glass G, Taylor JF, Lang CA, 1983, The effect of donor and cell age on several characteristics of rat erythrocytes, Exp Hematol, 11, 987-95.

15. Grindem CB, 1989, Bone marrow biopsy and evaluation, Vet Clin North Am Small Animal Pract, 19 669-96.

16. Hawkey CM, Hart MG, Bennett Pm, 1990, Diagnostic value of platelet caunts in mammals, Vet Rec $127,18,265-78$.

17. Jovanović M, Đurđević D, Mirilović M, Ilić V. 2005, Radijacijske promene u perifernoj krvi pacova Zbornik kratkih sadržaja. 11. godišnje Savetovanje veterinara republike srpske (Bosna i Hercegovina), Teslić, Banja Vrućica, 110.

18. Jovanović M, Mirilović M, Đurđević D, llić V, 2005, Prikaz dejstva različitih doza zračenja na hematološke parametre pacova soja Wistar. Proceedings Workshop "Clinica Veterinaria", AGR 20416, Ohrid, 355

19. Lake FD, Akporiaye TE, Hersh ME, 2001, Immunopharmacology. In Katzung GB, Basic \& Clinical Pharmacology, By, $8^{\text {th }}$ edition, Lange Medical Books/Mcgraw-Hill, 959-86.

20. Milošević H, Saračević Lejla, Hadžijunuzović Dženita, 2004, Radijacijske promene u perifernoj krvi domaćih životinja, Veterinaria, Sarajevo, 53, 2-4, 179-92.

21. Miura G, Awaya H, Matsumoto T, Tanaka N, Matsunaga N, 2000, Dose Granulocite Colonystimulating Factor Exacerbate Radiation-induced Acute Lung Injury in Rats, Rad Med, 18, 4, 227-32.

22. Montoya JA, Martinez EM, Rodriguez M, Perez-Cuadrado S, 1990 Immunochemotherapy (thymostimulin/cyclophosphamide) in dog, Br Vet J, 146, 3, 249-54.

23. Munno Irene, Marinaro Mariarosaria, Gesario Antonia, Cannusc, Mishel Yvonne, Paulling Emily, 1995, Immunomodulatory Effects of Alfa Interferon and Thymostimulin in patient with neoplasias, Clin Diagn Labor Immunol, 2, 4, 503-5.

24. Nesterova IV, 1999, Modern Immunotherapy in Clinical Medicine; Present and Future. Russ $J$ Immunol., 4(4), 322-26.

25. Ossowicka-Stepinska J, Engel-Pietrzak K, Ronin-Walknowska E, 1999, Therapeutic aplication of TFX and ubiquitin complex in pregnant rabbits with antiphospholipid syndrome, Int $J$ Thymol, 7, $12+13,596-600$

26. Radojčić Č, Andrić B, Simović M, Dujić A, Marinković D, 1990, Genetics basis of resistance to trauma in inbred strains of mice, $J$ Trauma, 30, 2, 211-4.

27. Ricould M, Dutrillaux, 1991, Variations of chromosome radiation sensitivity in fetal and adult mice during gestation, Mutat Res, 250, 1-2, 331-5.

28.Simović $M, 1983$ Uticaj cistafosa na tok i ishod udružene radiacione povrede, Specijalistički rad, Vojnomedicinska Akademija, Beograd.

29. Tizard RI, Schubot M R, 2004, Veterinary Immunology. An Introduction. $7^{\text {th }}$ edition, WB Sounders Company, Philadelphia.

30. Vučković-Dekić Lj, Stanojević-Bakić N, Rajner L, Frim O, Dekić M, 1994, In Vitro Immunorestorative properties of Thymex-L and TFH-Thymomodulin, Int J Thymol, 2, 3, 134-41.

31. Wilson LJ, 1999, Thymus Extracts: An International Literature Review of Clinical Studies. Foundation for Immunology and Nutrition, development, Education nd Research, 100-29,

32. Ziablitski VM, Staroselskaia AN, Romanovskaia VN, Zhavoronkov LP, Mikhalskaia TI, 1997, An experimental study of the hemostatic system in acute radiation sickness exacerbated by skin burns, Rad Biol Radioecol, 37, 1, 68-75 


\section{EFEKAT TIMUSNOG EKSTRAKTA NA VREDNOSTI HEMATOLOŠKIH PARAMETARA OZRAČENIH WISTAR PACOVA}

JOVANOVIĆ M, LAZAREVIĆ M, POPOVIĆ N i ĐURĐEVIĆ D

\section{SADRŽAJ}

U ovom radu su izneti rezultati ispitivanja efekta preparata Thymex-L dobijenog iz ekstrakta goveđeg timusa na dinamiku promena osnovnih hematoloških parametara pacova soja Wistar kod kojih je prethodno izvršeno jednokratno ozračivanje celog tela X zracima u ukupnoj dozi od 4 Gy. Nakon 28 dana ogleda i sukcesivnog praćenja vrednosti ispitivanih parametara, registrovano je statistički značajno povećanje ukupnog broja leukocita, broja limfocita i neutrofilnih granulocita, počevši od 14. dana ogleda u grupi ozračenih pacova tretiranih ekstraktom timusa. Do značajnog povećanja broja monocita došlo tek 28. dana. Statistički značajno povećanje broja eritrocita, koncentracije hemoglobina, hematokritske vrednosti i broja trombocita registrovano je počevši od 21 dana ogleda pa sve do kraja ispitivanja. 